ERNST, W. 1975. Variation in the mineral contents of leaves of trees in miombo woodland in south central Africa. Journal of Ecology 63:801-807.

FELKER, P. 1978. State of the art: Acacia albida as a complementary permanent intercrop with annual crops. University of California, Riverside, California. 133 pp.

GUY, P. R. 1981a. Changes in the biomass and productivity of woodlands in the Sengwa Wildlife Research Area, Zimbabwe. Journal of Applied Ecology 18:507-519.

GUY, P. R. 1981b. The estimation of the aboveground biomass of the trees and shrubs in the Sengwa Wildlife Research Area, Zimbabwe. South African Journal of Wildlife Research 11:135-142.

JUNG, G. 1969. Cycles biogéochimiques dans un écosystème de region tropicale seche Acacia albida (Del.) sol ferrugineux tropical peu lessivé (DIOR). Oecologia Plantarum 4:195-210.

KIRMSE, R. D. \& NORTON, B. E. 1984. The potential of Acacia albida for desertification control and increased productivity in Chad. Biological Conservation 29:121-141.

PROCTOR, J. 1984. Tropical forest litterfall II: the data set. Pp. 83-113 in Chadwick, A. C. \& Sutton, S. L. (eds). Tropical rain forest ecology and management, supplementary volume. Leeds Philosophical and Literary Society.

SCHOLTZ, C. H. 1982. Trophic ecology of Lepidoptera larvae associated with woody vegetation in a Savanna ecosystem. South African National Scientific Programmes Report No. 55, CSIR, Pretoria.

TOLSMA, D. J., ERNST, W. H. O., VERWEIJ, R. A. \& VOOIJS, R. 1987. Seasonal variation of nutrient concentrations in a semi-arid savanna ecosystem in Botswana. Journal of Ecology 75:755-770.

VITOUSEK, P. 1982. Nutrient cycling and nutrient use efficiency. American Naturalist 119:553-572.

VITOUSEK, P. 1984. Litterfall, nutrient cycling and nutrient limitation in tropical forests. Ecology 65:285-298.

VAN WYK, P. 1972. Trees of the Kruger National Park. Purnell, Cape Town.

WICKENS, G. E. 1969. A study of Acacia albida Del. (Mimosoideae). Kew Bulletin 23:181-202.

Accepted 29 July 1988

\title{
ANNOUNCEMENT
}

\section{Data wanted on phenology}

We are writing a review on plant phenology (leaf, flower, fruit, and seed/germination). We know that many researchers have collected phenological data as background information for studies with other objectives. We are trying to review phenological patterns on a global scale, and in many ecosystems there are few published accounts. If you have data you would be willing to contribute on phenology we would be interested in hearing from you. All contributions will be properly acknowledged in the review. We would greatly appreciate a detailed description of the methods used in collection of these data. We would also appreciate reprints and manuscripts in press or in review.

\section{T. Mitchell Aide and Todd Dawson}

Department of Biology, University of Utah, Salt Lake City, UT 84112, USA.

(Telephone: $8015817086 / 5927)$ 